\title{
BMJ Global Health Prepared for the 'unexpected'? Lessons from the 2014-2016 Ebola epidemic in West Africa on integrating emergent theory designs into outbreak response
}

\author{
Janice E Graham, ${ }^{1}$ Shelley Lees, ${ }^{2}$ Frederic Le Marcis, ${ }^{3}$ Sylvain Landry Faye, ${ }^{4}$ \\ Robert R Lorway, ${ }^{5}$ Maya Ronse, ${ }^{6}$ Sharon Abramowitz, ${ }^{7}$ Koen Peeters Grietens ${ }^{6,8}$
}

\begin{abstract}
To cite: Graham JE, Lees S, Le Marcis F, et al. Prepared for the 'unexpected'? Lessons from the 2014-2016 Ebola epidemic in West Africa on integrating emergent theory designs into outbreak response. BMJ Glob Health 2018;3:e000990. doi:10.1136/ bmjgh-2018-000990
\end{abstract}

Handling editor Seye Abimbola

Received 5 June 2018 Revised 22 June 2018 Accepted 24 June 2018

Check for updates

(c) Author(s) (or their employer(s)) 2018. Re-use permitted under CC BY-NC. No commercial re-use. See rights and permissions. Published by BMJ.

For numbered affiliations see end of article.

\section{Correspondence to} Koen Peeters Grietens; kpeeters@itg.be
How prepared were we for this most recent Ebola outbreak? Real-time emergent research is imperative for successful response to global health emergencies. While innovative biomedical interventions are certainly important, ${ }^{1}$ local on-the-ground realities during the 2014-2015 West African Ebola epidemic demanded a different though complementary set of research skills. Effective response required deep, sensitive understandings of emergent local dynamics and flexible, emergent solution. Emergency intervention called for evolving, flexible emergent methods that produced and translated rapid knowledge throughout the crisis. Yet, the need for emergent theory methodologies such as ethnography that actively witness and document the unforeseen consequences of emergencies and their response receives little attention in preparedness strategies. ${ }^{2}$

Global health community preparedness and response largely hinges on the rapid financialisation and development of innovative medical interventions. ${ }^{3-5}$ However, even seemingly straightforward interventions, such as vaccine delivery, require real-time awareness of emergent on-the-ground local ('field') realities. Research that legitimately engages with communities in crisis to genuinely localise interventions demands dialogue with and by communities. Such research is often narrowly conceptualised as 'communication', ${ }^{67}$ which ignores the socioeconomic, political and historical nature of vulnerability to disease and its transmission. ${ }^{8}$ The limits of communication, when conceived as a top-down deployment of knowledge by national and international actors, have been identified as one of the main shortcomings of the response to other epidemics of our time, such as the HIV/AIDS pandemic. At the beginning of the West African Ebola

\section{Summary box}

Even seemingly straightforward interventions, such as vaccine delivery, require real-time awareness of emergent on-the-ground local ('field') realities.

- Outbreak response requires thoughtful engagement that include local communities from the start.

- Methodologies to actively witness, document and integrate unexpected events and consequences of implementations in response are needed.

- Emergent theory designs hold important disciplinary and methodological implications for implementing and delivering interventions.

- Emergent theory designs, such as ethnography, are an essential part of effective outbreak response, capturing emerging barriers and facilitators in real time and bridging local and global realities.

epidemic, anthropologists cautioned against approaches that would draw on overly simplistic interpretations of risky behaviours and traditional practices. ${ }^{9}$

Beyond the hopes placed on new treatments and vaccines, reinforced by communication and sensitisation strategies, there is a need for preparedness in mechanisms, that is, methodologies to actively witness and document unexpected events and unforeseen consequences of implementations and ways to integrate those factors in the response. This has received little attention. Unexpected pre-existing social factors, as well as unintended consequences of the response itself are inevitable. Emergencies necessarily call for emergent methodological approaches that involve flexible adaptations that will rapidly produce effective scientific knowledge about sociopolitical structures and human behaviours in local and national field contexts for an effective response.

Emergent research designs, such as ethnography, involve data collection and analytical procedures that evolve over the course of 
an outbreak ${ }^{10}$ and entail a constant iterative research process allowing for the inclusion/capturing of unpredictable factors that characterise emergencies. Countless examples of emergent approaches proved effective during the Ebola crisis.

In West Africa, as in many cultures around the world, proper mourning and burial is necessary for a dignified passage after death. At the beginning of the outbreak, frightened and without prior experience of the disease, some Guineans, Liberians and Sierra Leoneans reacted violently when sick family members were removed from their communities, not to be seen again. After anthropological interventions mediated emergency response teams and bereaved communities, safe and dignified burial practices were implemented. ${ }^{11-14}$

Discrepancies between expectations and actual practices posed a different set of challenges for Guinean Muslims (90\% of the population) with regard to vaccination. Although vaccination is permitted according to most Muslim scholars, more than half of the Guineans interviewed during the crisis considered vaccination for the clinical trials of the candidate Ebola vaccines impious during Ramadan fasting. With the assistance of imams, context-sensitive accommodations were negotiated to assuage these emergent concerns. ${ }^{15}$

The negotiation of trust and the need for an understanding of local micropower dynamics became essential as the response unfolded. Trust is probably the most decisive condition for successful health interventions and has been shown to be key for strategies such as vaccinations. The start of a vaccine trial in Sierra Leone revealed the unexpected inability and unwillingness of local leaders to act as spokespeople for the trial in their communities, as they had witnessed the subversion of their power by national and international organisations responding to the outbreak. ${ }^{16}$ In Guinea, in order to involve Ebola virus disease survivors in a convalescent plasma trial as providers of the experimental therapy, gaining trust from survivors' communities and their networks was a condition to the effective implementation of the trial and entailed a complex negotiation process between several micropowers, local partnering institutions and the research team which had to be constantly rebuilt/ maintained throughout the implementation and posttrial phase. Anthropologists contributed to documenting those processes and 'monitoring' the relationships during the trial, with the close involvement of a key interlocutor. Taking into account what are essential but often hidden and unspoken power relations within communities was fundamental to effective communication and implementation. Regular interactions with people in communities at every level, from villages, to local and national leaders, to multilateral boardrooms, allowed the definition of adapted strategies to these emerging barriers and pointed to overly shallow interpretations associated, for example, with recurring violence attributable to ethnic specificities.
The need for emergent theory designs holds important disciplinary and methodological implications for implementing and delivering interventions and are an essential part of effective outbreak response, capturing emergent barriers and facilitators in real time, bridging local and global realities and contributing to alleviating suffering during epidemics. ${ }^{17}$

\section{Author affiliations}

${ }^{1}$ Technoscience and Regulation Research Unit, Faculty of Medicine, Dalhousie University, Halifax, Nova Scotia, Canada

${ }^{2}$ Department of Global Health and Development, London School of Hygiene and Tropical Medicine, London, UK

${ }^{3}$ Département des Sciences Sociales, Ecole Normale Superieure de Lyon, Laboratoire des Enjeux Contemporains (LADEC, FRE 2002, CNRS Lyon 2, ENS-L), Lyon, France

${ }^{4}$ Département de Sociologie, Universite Cheikh Anta Diop, Dakar, Senegal ${ }^{5}$ Canada Research Chair in Global Intervention Politics and Social Transformation, University of Manitoba, Winnipeg, Manitoba, Canada

${ }^{6}$ Department of Public Health, Medical Anthropology Unit, Institute of Tropical Medicine, Antwerpen, Belgium

${ }^{7}$ Independent researcher, USA

${ }^{8}$ Public Health, Institute of Tropical Medicine, Antwerp, Belgium

Acknowledgements The Global Vaccines Logic workshop where these ideas were developed was supported by the Canadian Institutes of Health Research (CIHR).

Contributors All authors equally contributed to writing the manuscript.

Funding This study was funded by Institute of Health Services and Policy Research (148908).

\section{Competing interests None declared.}

Patient consent Not required.

Provenance and peer review Not commissioned; externally peer reviewed. Data sharing statement There are no data applicable for this commentary

Open access This is an open access article distributed in accordance with the Creative Commons Attribution Non Commercial (CC BY-NC 4.0) license, which permits others to distribute, remix, adapt, build upon this work non-commercially, and license their derivative works on different terms, provided the original work is properly cited, appropriate credit is given, any changes made indicated, and the use is non-commercial. See: http://creativecommons.org/licenses/by-nc/4.0/.

\section{REFERENCES}

1. Brende B, Farrar J, Gashumba D, et al. CEPI-a new global R\&D organisation for epidemic preparedness and response. Lancet 2017;389:233-5.

2. Røttingen JA, Gouglas D, Feinberg M, et al. New vaccines against epidemic infectious diseases. N Engl J Med 2017;376:610-3.

3. Wellcome Trust/CIDRAP report. Completing the development of ebola vaccines. 2017. http://www.cidrap.umn.edu/completingdevelopment-ebola-vaccines

4. Butler D. Billion-dollar project aims to prep vaccines before epidemics hit. Nature 2017:541:444-5.

5. Røttingen JA, Gouglas D, Feinberg M, et al. New vaccines against epidemic infectious diseases. N Engl J Med 2017;376.

6. Wilkinson A, Parker M, Martineau F, et al. Engaging 'communities': anthropological insights from the West African Ebola epidemic. Philos Trans R Soc Lond B Biol Sci 2017;372:20160305.

7. Global Ebola Vaccinelmplementation Team (GEVIT)Practical guidance on the use ofEbola vaccine in an outbreakresponse. 2016. http://www.who.int/csr/resources/publications/ebola/gevit guidance_may2016.pdf?ua=1

8. Corin E. et a/The social and cultural matrix of disease. In: Robert G, Evan s, Morris LB, Theodeore Marmor, . Why are some people healthy and others not? The determinants of the health of populations. New York: Aldine de Gruyter, 1994.

9. Chandler C, Fairhead J, Kelly A, et al. Ebola: limitations of correcting misinformation. Lancet 2015;385:1275-7.

10. Morgan DL. Emergent Design. The Sage encyclopedia of qualitative research methods: Sage Thousand Oaks, 2008. 
11. Anoko J. La réparation de la malédiction générale suite à l'enterrement d'une femme enceinte avec le bébé dans le ventre. Une approche anthropologique pendant l'épidémie de la Maladie à Virus Ebola en Guinée. 16p, 2014. https://f-origin.hypotheses.org/ wp-content/blogs.dir/2225/files/2015/01/La-r\%C3\%A9paration-dela-mal\%C3\%A9diction-g\%C3\%A9n\%C3\%A9rale-Julienne-Anoko2014-12-22.pdf

12. Fairhead J. The significance of death, funerals and the afterlife in Ebola-hit Sierra Leone, Guinea and Liberia: Anthropological insights into infection and social resistance. 25: » Briefing paper, 2014. http:// www.ebola-anthropology.net/key_messages/the-significance-ofdeath-funerals-and-theafter-life-in-ebola-hit-sierra-leone-guinea-andliberia-anthropological-insights-into-infection-andsocial-resistance/

13. Faye SL. "L'« exceptionnalité » d'Ebola et les « réticences » populaires en Guinée-ConakryRéflexions à partir d'une approche d'anthropologie symétrique ", Anthropologie \& Santé [En ligne], 11 | 2015, mis en ligne le 30 novembre 2015, consulté le 27 juin. 2017. http://anthropologiesante.revues.org/1796
14. Le Marcis F. « «Traiter les corps comme des fagots » Production sociale de l'indifférence en contexte Ebola (Guinée) ", Anthropologie \& Santé [En ligne], 11 | 2015, mis en ligne le 29 novembre 2015, consulté le 10 décembre. 2015. http://anthropologiesante.revues. org/1907

15. Peiffer-Smadja N, Ouedraogo R, D'Ortenzio E, et al. Vaccination and blood sampling acceptability during Ramadan fasting month: A cross-sectional study in Conakry, Guinea. Vaccine 2017;35:2569-74.

16. Enria L, Lees S, Smout E, et al. Power, fairness and trust: understanding and engaging with vaccine trial participants and communities in the setting up the EBOVAC-Salone vaccine trial in Sierra Leone. BMC Public Health 2016;16:1140.

17. National Academies of Sciences, Engineering, and

Medicine. Integrating clinical research into epidemic response. The Ebola experience (2017). Washington, DC: The National Academies Press, 2017. https://doi.org/10.17226/24739 